\title{
Sustainability Indicators: Relevance, Public Policy Support and Challenges
}

\author{
Andre C. S. Batalhao ${ }^{1}$, Denilson Teixeira ${ }^{2}$, Maria de Fatima Martins ${ }^{3}$, Hans Michael van Bellen ${ }^{4} \&$ Adriana \\ Cristina Ferreira Caldana ${ }^{5}$ \\ ${ }^{1}$ Center for Environmental and Sustainability Research (CENSE), Nova Lisbon University, Caparica, Portugal \\ ${ }^{2}$ School Civil Engineering, Federal University of Goias, Goiania, Brazil \\ ${ }^{3}$ Humanities Center, Federal University of Campina Grande, Campina Grande, Brazil \\ ${ }^{4}$ Knowledge Engineering Department, Federal University of Santa Catarina, Florianopolis, Brazil \\ ${ }^{5}$ School of Economics, Business Administration and Accouting, University of Sao Paulo, Ribeirao Preto, Brazil \\ Correspondence: Andre C. S. Batalhao, School of Science and Technology, Department of Environmental \\ Sciences and Engineering, Nova Lisbon University, Caparica, Portugal. E-mail: andre.ciamb.ufg@gmail.com
}

Received: October 20, 2019

Accepted: November 20, 2019 Online Published: November 29, 2019

doi:10.5539/jms.v9n2p173

URL: https://doi.org/10.5539/jms.v9n2p173

\begin{abstract}
Sustainability is a topic that has gained importance in several fields of knowledge, including the public, private and society spheres, based on the discussions that involve the definition of several public policies. Sustainability Indicators (SI) are metrics that seek to measure the level of sustainability and compile information for better decision-making concerning policies, programs, projects and actions related to sustainability. Demonstrated their relevance to public policies the SI appears as an essential tool for evaluating development goals as a sustainable proposal. In this way, this research aimed to discuss the main challenges and methodological limitations found in the use of SI, emphasizing the main fragilities identified in the literature. In methodological terms, the research has exploratory characteristics, supported by the mixed methods approach using a theoretical-empirical analysis, from the available literature on the subject and the methodologies used and the experience of researchers about the topic addressed. The main results demonstrated that Sustainability Indicators are tools that should be used to define, implement, evaluate and monitor public policies at all levels, considering the potentialities/weaknesses and priorities of each context.
\end{abstract}

Keywords: sustainability indicators, challenges, sustainable development, sustainability assessment

\section{Introduction}

In the 1970s and early 1980s, the conservation and preservation of natural resources and the role of man integrated with the environment began to play a very important role in discussing the quality of life of the population. The path towards sustainable development (SD) has been identified as an important political process, and determining for spatial planning (Cassar et al., 2013; Büyüközkan \& Karabulut, 2018) to incorporate the principles of sustainability into the development process on a local and global scale (Ramos, 2019).

In this sense, the emerging need to develop strategies that help communities move towards sustainability is crucial, bringing together research and practice in contemporary planning to identify different challenges (Gillen \& Scanlan, 2004; Michael et al., 2014). Based on the concept of quality of life (Hedlund-de Witt, 2014; Uysal \& Sirgy, 2019; Huovila et al., 2019), wishes and opinions about sustainability indicate to the importance of mitigating actions and impact minimization gathering subsidized alternatives with reliable and solid parameters, to be considered as sustainability monitoring and management model at all levels. In the context of SD, the adoption of a transition perspective is related to decision-making strategies, which aim to promote the improvement of public environmental and sustainability policies, considering these essential aspects in this process (Waas et al., 2014; Nogueiro \& Ramos, 2014).

The current global crises have led us to think of a new structure of public policies, making them effective for the construction of systems that help in decision making, resulting in the creation of guidelines that incorporate into the planning real benefits in terms of sustainability. Based on the initiative of the Millennium Development 
Goals (MDG), the UN approved the Sustainable Development Goals (SDG) in the 2015, in order to provide guidance to achieve SD. The SDG can facilitate more sustainable development, through their application to different levels using SI (Zinkernagel et al., 2018). It still is not clear how overcome the barriers regard to implementing SDG, or how society actively contribute and get involved in the global challenge of reaching sustainability (Graute, 2016). Assessing the sustainability of development, it is necessary to build indicator systems that take into account the principles of the $\mathrm{SD}$, which allow the identification of current situation information (Ramos, 2009, 2019), promoting useful information for the decision-making in public policies.

The use of indicators can improve decision quality and trigger more effective actions by simplifying, clarifying, and making aggregate information more accessible to decision-makers (Hai et al., 2014; Fredericks, 2012). In this context, the SI have been tools used to help the understanding of the concept of sustainability, based on a methodological approach connected to the new paradigms of SD. From this perception, several researchers using SI have discussed the relevance of indicators and their periodic maintenance, revealing the difficulties in the credibility of their results, often not reflecting the reality of an individual, place, region, nation with a margin of reasonable confidence (see the work of Hák et al., 2016; Janoušková et al., 2019).

Sustainability assessment using indicators may be outdated or redundant due to a set of factors or difficulties in the sustainability selection, operationalization, analysis, and monitoring process, as discussed by Martins and Cândido (2015). According to the same authors, we can see also: the information gap; the lack of a consolidated and periodically powered database; the unavailability of data for smaller geographic spaces (municipalities, neighborhoods, census tracts, communities) or for specific contexts (rural, urban, economic activities); the difficulties of building methods that capture the subtleties and subjectivity of sustainability in each specific context, resulting in a coherent analysis; beyond the obstacles that make it impossible to monitor the levels of sustainability of development.

In addition, it is noted that although indicators have been widely used, there are limitations that need to be considered. There is still no universally accepted set of indicators (Parris \& Kates, 2003), and several methodological difficulties are encountered in using these variables at different levels and time clipping. Table 1 demonstrates the SI challenges selected for this revision, according to their repetition by literature, ranked in the following categories described below. 
Table 1. Analysis of the selected SI challenges identified in literature by categories

\begin{tabular}{ll}
\hline Categories of selected challenges & Summary of rationale \\
\hline $\begin{array}{l}\text { \#a. Methodological consensus and } \\
\text { standardization }\end{array}$ & $\begin{array}{l}\text { Identify common bases using SI to facilitate } \\
\text { comparative analysis between different initiatives and } \\
\text { assessment levels, covering scales and cases in } \\
\text { various contexts. Combining into a sustainability } \\
\text { assessment aggregation method all relevant } \\
\text { information, using underlying indicators. }\end{array}$ \\
& \\
\hline \#b. Inference and quality of data & $\begin{array}{l}\text { Improve to reliable data by providing accurate } \\
\text { information to users' conclusions to better supporting } \\
\text { decision-making processes, as well as reporting } \\
\text { initiatives. }\end{array}$ \\
& \\
& \\
\hline \#c. Lack of data and database & Develop databases stressing the open access to \\
limitations & $\begin{array}{l}\text { available data and information for the sustainability } \\
\text { themes, providing transparency in collecting and data } \\
\text { processing, including information transfer time. }\end{array}$ \\
&
\end{tabular}

Reference

Moreno Pires et al. (2014)

Mascarenhas et al. (2010)

Zhang \& Guindon (2006)

Gasparatos et al. (2008)

Jeníček (2013)

Rinne et al. (2013)

Mascarenhas et al. (2010)

Bixler et al. (2019)

Conway (2007)

Alshuwaikhat et al. (2017)

Mascarenhas et al. (2014)

Ramos \& Caeiro (2010)

Van Dijk et al. (2014)

Mascarenhas et al. (2015)

Janoušková et al. (2019)

Hildén \& Rosentröm (2008)

Ridolfi et al. (2008)

Gasparatos et al. (2008)

Latawiec \& Agol (2016)

Lozano \& Huisingh (2011)

De Kerk \& Manuel (2008)

Souto et al. (2009)

Davidson (2011)

Gutowska et al. (2012)

Kelly et al. (2018)

\#d. Covering mechanisms for SI use at different levels

Define the level of reach of SI mechanisms, including opportunity for local, regional and national reporting. Approaches to understanding effective ways to influence public policy and decision-making processes based on citizen expectations, including selection of better indicators for that.

Ronseström (2018)

Morse (2016)

Dahl (2012)

Graymore et al. (2008)

Graymore et al. (2010)

Nourry (2008)

Balsa-Barreiro et al. (2019)

\#e. Legitimacy and political and thematic relevance

Identify the indicators' value in different levels to operational strategies, highlighting policy making and actions towards sustainable goals. The structure of the indicator should maintain its appropriate level, where it can be legitimized by political acceptance and an appropriate conceptual approach, ensuring credibility.

\begin{tabular}{|c|c|}
\hline \#f. Stakeholders' engagement & $\begin{array}{l}\text { Enlarge the perspective of a community by adding } \\
\text { individual sets of participatory indicators, focusing in } \\
\text { selecting method. Each stakeholder plays a central } \\
\text { and ambitious role in achieving goals and reporting } \\
\text { results, making it easier to identify root causes based } \\
\text { on everyone's engagement. It can promote visibility } \\
\text { to stakeholders from many territorial levels. }\end{array}$ \\
\hline $\begin{array}{l}\text { \#g. Subjectivity of SD concept, } \\
\text { scope and complexity }\end{array}$ & $\begin{array}{l}\text { An SD background theory integrating SI conceptual } \\
\text { approach could be essential to respond the most } \\
\text { important needs. The inexistence of the endogenous } \\
\text { scope may increase the complexity of the assessment } \\
\text { or management. }\end{array}$ \\
\hline
\end{tabular}

Hák et al. (2012)

Bell \& Morse (2018a)

Ramos et al. (2004)

Mascarenhas et al. (2015)

Verma \& Raghubanshi (2018)

Bell \& Morse (2018b)

Hák et al. (2016)

Holden (2013)

Janoušková et al. (2019)

Coutinho et al. (2017)

Kelly \& Moles (2002)

Dahl (2012)

Mascarenhas et al. (2014)

Perrini \& Tencati (2006)

Santos et al. (2006)

Farinha et al. (2019)

Milman \& Short (2008)

Pissourios (2013)

Michael et al. (2014)

Dahl (2012)

Gallopin (2018)

Malovics et al. (2009)

Moldan et al. (2012)
Domingues et al. (2018) 
The selected challenges were those commonly occurred in the topics researched, which does not state that there are no other specific categories. Other potential challenges may derive from these categories identified in the review, characterizing subsequent challenges.

Despite the relevance of indicators to support the definition, evaluation and monitoring of public policy results, the process of selection, operationalization, and analysis through indicators still presents challenges that compromise the achievement of more satisfactory results and therefore need to be overcome (Hák et al., 2016). In this sense, discussing such challenges and pointing out new perspectives (Verma \& Raghubanshi, 2018; Ramos, 2019) becomes essential for the process of SD to be incorporated into the most diverse geographical contexts. It is noteworthy that the context or geographic space itself prints realities that configure specific and sectoral challenges, which requires a thorough look, and appropriate analysis methods.

Based on the central issues and the relevance of the use of indicators for the process of assessment SD and redirecting public policies, it is appropriate to discuss some factors that hinder the use of SI, clarifying important issues to improve the adequacy of assessment aims.

The main goal of this paper was to gather the main challenges and methodological limitations found in the use of SI, highlighting the main weaknesses identified in the literature. In methodological terms, this research has an inductive-exploratory feature, in which the qualitative method approach was employed. Its combined elements of the qualitative approach (document collection and selection, structured content analysis) to understand theoretical sampling.

After the introduction, the scope and methodological approach of the research are presented, including the foundations for discussing SI challenges. Then, in Sections 3, 4 and 5 the main results are pointed out, and in Section 6, the final considerations are presented, including the contribution to the field of knowledge and the implications of the study.

\section{Scope and Methodological Approach}

In this study was made a critical evaluation of a set of initiatives for SI. Inductive-Exploratory research was conducted, in which the literature review was developed through a combination of qualitative methods for document analysis, followed by a classificatory evaluation procedure, as suggested by Saunders, Thornhill and Lewis (2012).

The documentary analysis focused primarily on the specific scientific literature on concepts, theories, methods, and case studies dealing with indicator-based sustainability assessment. The analysis of these documents was comparative, exploring the relevance and potential contribution to public policies in light of the initiatives identified in the research.

The research also highlights some disadvantages and limitations of SI, considering them as challenges for the theme. Although the search procedure predominantly followed a subjective approach, it was considered that documents that covered the topic objectively, minimally complying with the principles of sustainability. Research and questions that were not clearly presented or substantiated were discarded from the analysis process. The terms 'sustainable development indicators', 'sustainability indicators', 'public policy', 'relevance' and 'public policy' were used to support exploratory analysis.

Exploratory research has limitations associated with its methodological approach, such as generalization, reliability, and validity (Bryman, 2012), which were considered and corrected for analysis of the results of the collected documents, and at the moment of elaborating the final considerations about the study.

\section{Sustainability and Indicators: Concepts and Relevance}

The concern to develop effective strategies and to base decision-making in the public and private sectors regarding sustainability has emphasized the need to integrate information, parameters, data from different sources and different fields of knowledge. In general, indicators are understood as quantitative expressions, but related to sustainability carry qualitative attributions. This demonstrates the lack of more comprehensive indicators that are measurable, applicable and relevant at the international, national, regional and local levels, as discussed by Fernández and Selma (2009).

Bossel (1999) stresses that the indicator quantifies and simplifies complex phenomena and realities to a manageable amount of meaningful information, feeding the decision process and directing actions. It is also understood that SI is increasingly used by public administrations to consolidate their SD strategies, enabling tangible evaluations and monitoring, as highlighted in the results of Tanguay et al. (2010). As noted by Pintér et al. (2005), the SI should be sustained using clear data to the growing need for producing information, with 
transparency and better spatial and temporal resolution. The research developed by Dahl (2012), pointed out that SI is just a tool that, among other factors already mentioned, can influence a political process, demonstrating a more significant and visible effect.

Related to the indicators, Bork et al. (2016) argued that these metrics are indeed a model of reality, but cannot be considered reality itself, however, they must be analytically legitimate and constructed within a coherent methodology of measurement. From this perspective, it is possible to consider that SI can be used as an integral part of decision-making by adding information that can be associated with others obtained through other instruments and methods.

Rogmans and Ghunaim (2016) and De Sherbinin (2013) emphasizes that indicators aim to aggregate and quantify information, so that their significance is more evident, simplifying the information on complex phenomena to improve the communication process. The findings by Fernández and Selma (2009) revealed that it is important to point out that the goal of the indicators is not to provide an absolute measure of the sustainability of a territory or system, but to evaluate the distance from the set goals and to find out if the trends are advancing or setback.

Shen et al. (2011) stressed that SI can help determine successful strategies and policies aimed at achieving sustainability goals, overcoming management deformities. Thereat, as established by Azar, Holmberg, and Lindgren (1996), indicators should be formulated according to the overall and sustainability targets.

Agenda 21 (UN, 1992), in Chapter 40, outlines the objectives that are fundamental to providing consistent information and guiding public policy at all scales: (a) Achieve more relevant and cost-effective data collection and evaluation, through better identification of users in both the public and private sectors and their information needs at local, national, regional and international levels; (b) Strengthen local, provincial, national and international capacity to collect and use multisectoral information in decision-making processes and strengthen capacity for data collection and analysis for decision-making, particularly in developing countries; (c) Develop or strengthen local, provincial, national and international means of ensuring that SD planning in all sectors is based on reliable, timely and usable information; (d) Make relevant information accessible as and when required to facilitate its use.

There are number of initiatives related to SI and frameworks for SD. The revision of Singh et al. (2009) provides an overview various SI applied in policy practice around the world. This paper compiles the information of more than 40 types of indicators, highlighting formulation strategy, scaling, potential political impacts, and indicators processing methods. The most common are: Human Development Index (HDI), Genuine Savings (GSs), Green Net National Product (EDP) and SEEA, Sustainability Performance Index, Eco-Index Methodology, Living Planet Index, Ecological Footprint (EF), Sustainable Asset Management (SAM), Life Cycle Index, Urban Sustainability Index, City Development Index, Compass Index of Sustainability, The Sustainability Cities Index, Environmental Sustainability Index, Environmental Policy Performance Indicator, Environmental Performance Index, Environmental Vulnerability Index, Well-Being Assessment, Index for Sustainable Society, among many others.

In this discussion, it is important to differentiate development and growth indicators. Development indicators are more than growth indicators, as they reflect efficiency, sufficiency, equity and quality of life, proving to be more appropriate to measure sustainability. Meadows (1998) states that to measure sustainability we need indicators with potential for evolutionary change, these have to do with diversity, tolerance, creativity, open mind, education and telling the truth about the success or failure of experiences.

Thus, for indicators to be instruments of a change process towards the concept of SD, they must gather characteristics that allow: measuring different dimensions in order to grasp the complexity of social phenomena; enable the participation of society in the process of defining development; communicate trends, supporting the decision making process; and relate variables, since reality is neither linear nor one-dimensional and requires a coherent look at its complexity (Ramos, 2019; Mascarenhas et al., 2010; Guimarães \& Feichas, 2009; Santana-Medina et al. 2013).

\section{Sustainability Indicator Systems to Support Public Policies}

SI plays an important role in understanding the environment and its prospects for the future at all territorial levels. The functioning of modern society and its continuous flow of conduct must be synchronously embedded in the biological and social phenomena that permeate human activity, to harmonize the path to understanding the real sense of sustainability and improve the quality of decisions (Batalhão et al., 2018).

The decision-making process consists of several tools that support a decision or building a development process, 
wherein the case of sustainability, it is necessary to adopt indicators that can generate the perception of all dimensions of sustainability. At all scales, the importance of reliable and judicious parameters should be stressed to have a true picture of the dimension and its direction towards sustainability, whether it is progress or return (Duran-Encalada et al., 2009; Munier, 2011; Hák et al., 2012).

The achievement of sustainability, currently a globally aspiring, highlights concrete features at all territorial levels from its peculiarities, and responds to the problems and opportunities of each space, as identified by Mascarenhas et al. (2015). The selection of SI should reflect the situations and specificities of the assessed level while pointing to the need for regular production of statistics on the topics addressed.

The Global Agenda 21 should be considered as a practical reference, as it is an effort initiated at ECO-92, seeking international commitment to SD, as established by UN (1992). Chapter 40 describes a set of activities that are indispensable for the development and adoption of indicators to underpin decision-making at the international, national, regional, local and individual scales: developing SI, promoting the global use of SI, improving data collection and utilization, improving data evaluation and analysis methods, strengthening the ability to disseminate information and establishing a broad information structure. These activities should be developed synergistically with the principles of SD in a pragmatic, practical rather than utopian manner. Following the hierarchy of these activities can facilitate the adoption and creation of mechanisms for action and stakeholder participation, effectively disseminating insightful information on the various themes that underpin sustainability, as explored by Fraser (2006).

The lack of indicators to compose a system for monitoring and evaluation of the sustainability dimensions is still a major challenge at all levels, even though in the last two decades there has been a growing interest in the world about sustainability and how to measure it (Rogmans \& Ghunaim, 2016). Another issue that also deserves attention is that each indicator and each group of indicators must be in line with the proposed analysis of the territory or system so that its representation is relevant and assists the decision-making of government authorities. Indicators, like variables, can be included in the analysis to know their behavior in the model and answer a better policy or other question considered (Rogmans \& Ghunaim, 2016; Rogers et al., 2013).

The use of sustainability assessment tools, which are supported by indicators, strengthens the public policy archetype by providing mechanisms to understand the identity of the system under consideration (Hoko \& Hertle, 2006). According to Nourry (2008), information on practices and actions around sustainability should be built with tested and scientifically proven methodologies, so that the results are robust and reliable, showing the situational photography of the dimension, theme or system. Each object of analysis has its subjectivities and requires a set of indicators consistent with the needs and objectives to be assessed. Indicators are not just for policy purposes they help to achieve and adjust those policies. The development of indicators cannot be purely a technical or scientific process (Valentin \& Spangenberg, 2000), and the actual activities carried out and the limitations on the balance of human and ecological well-being must be transparent (Malovics et al., 2009).

Considering the issues addressed, SI systems, originally developed to alert people to the limits of natural living systems, are currently reaching limits where the need to promote social and political change is recognized (Holden, 2013). A project of indicators should consider their potential use in public policy formulation, and it is necessary to develop specific communication methods for resource allocation, indispensable for well-being and sustainability (Rinne et al., 2013).

The formulation of public policies must be firmly rooted and in tune with the potentialities and weaknesses of the system analyzed through the indicators grouped for it, seeking to point out effective improvements in the biophysical and human aspects of the system (Malovics et al., 2009). In this way, we seek balance within the sustainability (performance) ranges, in which the analysis was referenced, as they are solidarity and complementary aspects for the formulation of solutions.

The relevance of creating and using an SI set reflects the plurality of stakeholders' aspirations and demands (Mascarenhas et al., 2015; Domingues et al., 2017) impacting public policy, governance and even informing the population theme that themes permeate the topic, with the purpose of generating positive and substantial consequences in understanding the dynamics of new development models (Moreno-Pires \& Fidelis, 2012). In other words, it also reinforces the society's engagement to identify main system problem points, proposing solutions and corrective actions potentially useful.

Based on this perspective, indicator systems need to be developed, focusing on reflecting the characteristics and processes of development, guided by methods that allow extracting important information and coherent with such reality. Thus, the process of operational execution can facilitate the composition of the evaluation using indicators, simplifying assumptions about policy decisions and creation/maintenance of public policies (Rinne et 
al., 2012).

\section{Challenges to SI}

Sustainability practices or actions and their outcomes can be monitored and evaluated in many different ways (Hoernig \& Seasons, 2004; Jeníček, 2013), and indicators are generally cited as appropriate for such tasks, as well as to assist in setting the sustainable agenda (Bockstaller \& Girardin, 2003; Dalal-Clayton \& Krikhaar, 2007; Donnelly et al., 2007; Michael et al., 2014).

In many countries, only from the 21 st century, together with the elaboration of national SD plans, efforts were initiated for the adoption of SI. In this context, SD should be understood as a new concept of development, which seeks to meet socio-economic demands without conflicting with the environment (Ramos, 2009). In the development process, the related themes must be synergistically in operation, based on regulations of national/international agencies and institutions (Guy \& Kibert, 1998) to establish the guiding aspects of strategies and actions to achieve sustainability. In addition, indicators should be tools that support and enable evaluations of the results achieved (or not), also pointing to new demands to be incorporated into national, regional and local agendas. Thus, we should carefully select coherent indicators, taking into account the principles and objectives of the SD, as worked by Pintér et al. (2018).

The following figure presents the selected challenges to SI for identifying follow-up actions and potential subsequent impact on public policies and their relevance criteria. The Figure 1 summarizes key views on SI use as well as consequences for indicators implementing, and contrasts these with challenges in the literature review. 
Follow-up action

\section{Potential subsequent} impact

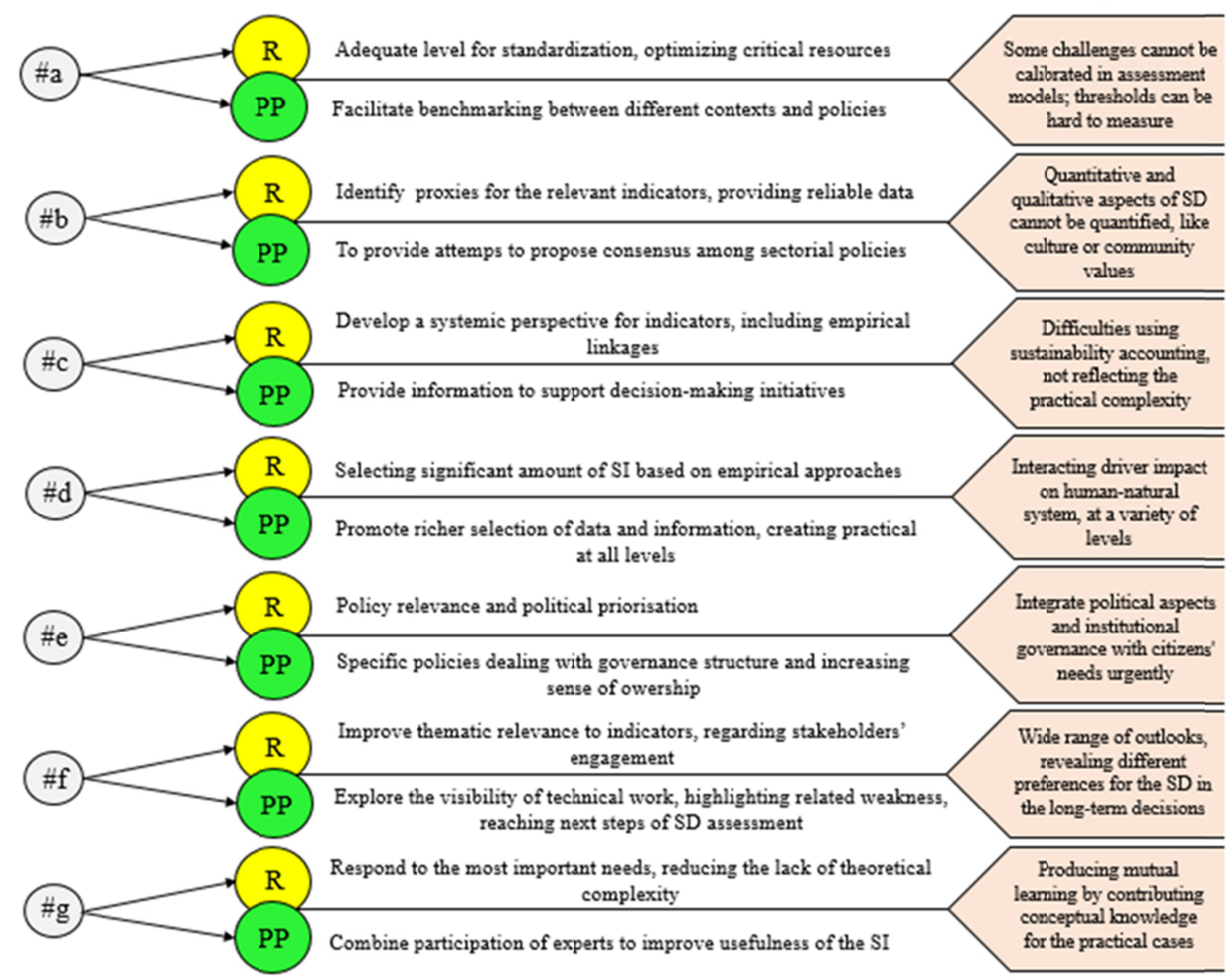

Legend

Figure 1. Summary of characteristics of each selected challenge 
The study of challenges to indicators were assessed in relation to the public policies and relevance topics, which is built on the initiatives of previous acknowledge and address the need to include upon sustainability issues. The different indicators initiatives have been demonstrating commons indicators sets covering SD dimensions, and to which they contrast with theoretical perspectives and in empirical terms. The interrelation of the challenges must be taken into consideration as it helps to position strategic elements, facilitating the fulfillment of sustainability goals. The more connections the challenge has, the greater its impact on society and other sectors of the global community, specifically for public policy relevance.

One of the relevant points in the use of indicators is that they have the function of generating data, which organized generate information, which when aligned with the objectives of the SD, result in knowledge that can be used to guide the process of preparing public policies aimed at sustainability (Ramos, 2019). In this construction, we can highlight the need to use reliable and permanent databases, formatting a diagnosis with historical and insightful information, proposing the understanding of its various themes, facilitating the perception of the quality and results of the implemented policies.

It should be understood that the developmental balance, driven by national and international standards that set sustainable standards, supports and assists the management of data sources. This helps to develop new solutions to guide and monitor public policies. In the case of SI, most research still has quantitative character, limiting the analysis of the results, not allowing a practical and theoretical deepening of the implications.

The qualitative approach cannot neglect mathematical, statistical, methodological care, etc., as if the method were done by the way, or were something secondary and supplementary. Qualitative research is more difficult and complex, precisely because it seeks to reduce the reductionism implicit in methodological formalization (Saunders et al., 2012). This concern is necessary for the results to be legitimately coherent and grounded, not forgetting the subjectivities and the various aspects of sustainability.

SI have multidimensional information and should be associated with the goal of SD, guided by human and ecological well-being (Fulford et al., 2017). As indicators have different measures and parameters, to aggregate indicators into themes, subthemes and dimensions, there are methodological approaches that standardize information into a single unit of measurement, transforming them into indices, which aggregate information from multiple indicators into a single index, which makes it possible to synthesize this information and facilitate the communication of results.

The selection of indicators or indices for use must be careful, as they must represent the reality of the system to be investigated. Thus, several authors have already adopted criteria to be used for a representative choice (see, for example, Pintér et al., 2012; Farinha et al., 2019; Verma \& Raghubanshi, 2018). However, it is important to emphasize that the choice of criteria depends on the objectives that guide the investigation. Ramos (2019) presents some basic criteria for the inclusion of an indicator in the sustainability analysis: a) represent an issue that is essential for the SD; b) be measurable quantitatively or qualitatively; c) be a relevant issue for the evaluated system; d) be or may be available; and e) can be understood by the general society.

Some barriers to the use of SI are being overcome, especially in recent years with the intensification of sustainability studies and indicators, global agreements and local agendas, policy demands, and government plans and programs for SD (Mascarenhas et al., 2010). We can note the expansion of SI for sustainability analysis in different geographic spaces such as nations, regions, municipalities, neighborhoods, communities, businesses, rural territories and individuals.

However, there are still many limitations not yet overcome, such as: lack of reliable and integrated data; low level of data availability; different periodicity (temporal interruption) of the data; fewer environmental indicators than socioeconomic indicators; Different levels of aggregation of indicators, among others, also emerged new challenges, mainly methodological.

Due to the need to meet the specific demands of each initiative, as well as to meet the public policies adopted in these contexts, it is possible to highlight new challenges: lack of consensus (Bixler, 2019) and cooperation between national and international organisations on the application, comparison and usefulness of the indicators for the new ones development patterns and definition of sustainability limits (ranges) (Gallopin, 2018); data for smaller geographic spaces (neighborhoods, communities, provinces, smaller municipalities) (Balsa-Barreiro, 2019; Verma \& Raghubanshi, 2018); the difficulty of using qualitative and quantitative indicators (Reinhardt et al., 2018); the decoupling of available indicators from public policies and development plans (Janoušková et al., 2019); the impossibility of making comparisons between geographical spaces (Tasaki \& Kameyama, 2015); divergences of information between different databases (Schliep et al., 2018), among many others. 
From the limitations pointed out regarding the use of SI, we can verify that the environmental, social, economic and institutional information are stored and treated separately when they should be understood as complementary and harmonic, as identified by Ramos (2019). It is the interaction of this information that meets the principles of SD and covers society to remedy historical injuries that may compromise the ecological and human balance in the present and future.

The low level of data availability can compromise the development of new public policies and weakens the construction of new indicators. It was clear that the largest unavailability of indicators was for smaller geographic spaces. As emphasized by Hák et al. (2016), this unavailability is a challenge to monitor the development of these spaces and the implementation of relevant public policies that allow incorporating a development process on a sustainable basis. Due to the lack of data for relevant indicators, the number of indicators used for sustainability analysis is reduced. About this, Tanguay et al. (2010) stressed that the number of indicators depends on the diversity of aspects present and the availability of data, where there are important gaps due to the absence of nationally consistent data for the construction of indicators.

Temporal disruption in data generation can make it difficult to analyze from longer time series, which results in the poor perception of sustainability by stakeholders and users. As discussed by Schliep et al. (2018), the temporal regularity in the generation of the data is important to build a comparative basis. In addition, continuous comparison of practices can lead to the development of standardized processes that can be used to guide the development of future attitudes (Shen et al., 2011). The discontinuity of data prevents the periodic analysis of sustainability and, consequently, the continuity of public policies that generated positive results for society.

Verma and Raghubanshi (2018) have argued that the unavailability of SI is one of the biggest obstacles to conducting sustainability analysis studies. This obstacle makes long-term and strategic assessments difficult due to the lack of long and consistent time series for some indicators. Pintér et al. (2018) argued that data availability and quality are considered a major technical challenge, coupled with the lack of monitoring mechanisms that provide adequate temporal and spatial resolution.

Synthesizing information without losing sight of sustainability goals is also a methodological challenge. Aggregating information into a single indicator from sub-indicators and other unweighted variables can distort the results and generate an analytically deficient index, as highlighted by Verma and Raghubanshi (2018). As indicated by De Sherbinin et al. (2013), this process typically involves the conversion of measures in a single standardized measure, according to its importance in the assessment system's overall view of sustainability. Indicators thereby provide a simplified and multidimensional view of an assessment system, as cited by Mayer (2008) and Bixler et al. (2019). However, the high level of aggregation could make myopic the vision around the problems, generating many difficulties of articulating strategies related to systematic weaknesses.

Rogmans and Ghunaim (2016) warns that a fundamental problem in aggregate indicators is the obscuration of information that threatens the effective visualization of the system, masking some sectors and highlighting others, being even more questionable when aggregation results in indices that condense different evaluation spheres. The author adds that without compatible dimensions, aggregation and overall comparisons will remain a problem for sustainability assessment. In this sense, the selection and aggregation of indicators into thematic indices and dimensions for forming an indicator system should be guided by an appropriate sustainability concept. De Sherbinin et al. (2013) argued that aggregation should be performed to synthesize a unique and complex meaning, and commonly presupposes some sort of weighting between simple indicators because not all indicators are equally important in constructing an index.

Given the subjectivity of sustainability and the need to use a large number of indicators, the weighting is an important resource for measuring sustainability levels and interpreting the subtleties of local, institutional and society-wide perceptions of priorities system vulnerability. In this case, the perspective for stakeholder participation in the indicator selection and weighting process is opened (Domingues et al., 2018), including quantitative and qualitative approaches as worked by Reinhardt et al. (2018).

The use of qualitative indicators allows us to extract current and more truthful information by capturing perception, on the other hand, analysis is difficult and often contradictions concerning quantitative data (Ali et al., 2019). In addition, qualitative indicators make it difficult or impossible to compare with other spaces investigated. The impossibility of making comparisons between geographic spaces can make it difficult to reproduce public policies in spaces of similar characteristics.

The findings of Pope et al. (2017) demonstrated that the lack of consensus and cooperation between national and international organisations on the application, comparison and usefulness of indicators (methodological 
resources) for new development patterns are challenges that may impede or hinder the achievement of sustainability goals and targets. The subjectivities of systems can hinder methodological standardization to understand sustainability issues, pursuing a holistic and integrative approach and accelerating political acceptance, as concluded by Bixler et al. (2019).

Notably, each set of indicators seeks to meet the aspirations of the territory where it was developed, but does not prevent cooperation between different systems. There may be similarities between different territories, which strengthens the methodological creation or maintenance of the indicators, promoting a technical evolution that supports the systems involved. Whenever possible, it is necessary to cooperate with other national and international indicator production projects, strengthening the discussion on the topic, understanding them as an integral part of the public policy management process.

Another important methodological challenge is the definition of the limits of sustainability, that is, the gap between what is sustainable and unsustainable, measuring the distance from sustainability (Hák et al., 2018). It is necessary to define sustainability ranges based on parameters that will support sustainability assessment tools, gathering reliable references to value the performance of each indicator. Fulford et al. (2017) and Ramos (2019) states that sustainability dimensions are large conceptual boxes that accommodate interests and concerns.

Different theories about SD and the creation of SI result in the development and application of different conceptual frameworks. These conceptual frameworks can help clarify what to measure, what to expect from the measurement, and what kind of indicators should be used, as highlighted by Pintér et al. (2005).

The distance that can occur between sustainability purposes and indicator systems is another challenge. This is a challenge that hinders the definition of appropriate public policies and, consequently, the continuity of those that generate positive results, the discontinuity of other inefficient ones or the adjustment to better serve the purposes of the SD.

The use of indicators within the sustainability movement is a simultaneous challenge of relevance, credibility, and legitimacy (Holden, 2013). Indexes and sets of indicators are constantly challenged by changes in social and natural conditions and scientific discoveries, which open new questions and changes in public policy (Rinne et al., 2013).

A discussion of these boundaries forces us to think about their implications, going beyond traditional disciplinary boundaries (Moldan et al., 2012), from more flexible methods that incorporate stakeholder participation democratically, as revealed by Domingues et al. (2018). Researchers need to incorporate into their framework of application and methodological approach the conceptual orientations that align with the demands of society, seeking to discuss and implement more equitable, equitable and fair development models. This reveals a need to build indicator systems that allow continuous monitoring, generating useful information for redefining public policies and incorporating more sustainable practices, resulting in better perspectives for the planet.

\section{Final Remarks and Further Reflections}

The purpose of the SI is the promotion of corrective and preventive practices and actions, generating situational portraitspictures, not forgetting past moments, anticipating adverse future situations. It also enables efficient and auxiliary diagnostics by supporting SD-connected public policies. However, to capture the complexity of public policies systems, monitoring needs to inlude qualitative approach. A number of the targets and goals to sustainability are formulated qualitatively rather than quantitatively. In addition, it is unclear how far the indicators will cover the qualitative aspects. We need identify relevant indicators that enable the assessing of crucial SD elements.

Indicators need to be constructed and validated through methodological models focusing on sustainability issues and aligned with a consistent and cohesive conceptual basis. Subjective indicators need to be turned into objective indicators, that is, of particular orientation towards a more consensual scope. This means that we must articulate international goals and objectives with national, regional and local goals.

SI are associated with different sustainability strategies at different scales or levels. The interaction of scales or levels in this type of monitoring tool is very scarce and poorly analyzed in the current literature, particularly between local and regional scales. Mascarenhas et al. (2010) argued that despite efforts to develop SI conceptual frameworks and systems, the absence of a formal sustainability strategy limits and weakens the effective interaction between sustainability assessment and society.

Usability is also an important factor because the vast majority of methods have little or no use by public and private sectors or other stakeholders after their creation. This makes us reflect on the real need to strengthen reporting mechanisms for progress or return to sustainability, to promote and ensure the sustainability of 
development.

New theoretical approaches have been developed to understand how stakeholders act and interact with each other and the territory in which they play their role, and how important they are in selecting, developing and evaluating SI. Ramos (2009) highlights that stakeholder engagement in this process is a major challenge, but necessary.

As proposed in this research, this paper has identified some of the main challenges and methodological limitations common in the use of SI identified in the literature. It has become clear that the multiple and complex dimensions of the concept of sustainability, recognizing closely related environmental, social, economic and institutional aspects and implications, constitute a major theoretical and practical challenge. Additional research should be developed to identify when and where these challenges are most present in the literature, identifying the main gaps, guiding new research fronts.

\section{Acknowledgments}

A special thanks to colleagues from Center for Environmental and Sustainability Research (CENSE) and Global Organization Learning and Developing Network (GOLDEN) for valuable guidance, insights and thoughts. We thank anonymous reviewers for their comments.

\section{References}

Ali, M., Geng, Y., Robins, D., Cooper, D., Roberts, W., \& Vogtländer, J. (2019). Improvement of waste management practices in a fast-expanding sub-megacity in Pakistan, on the basis of qualitative and quantitative indicators. Waste Management, 85, 253-263. https://doi.org/10.1016/j.wasman.2018.12.030

Alshuwaikhat, H. B., Abubakar, I. R., Aina, Y. A., Adenle, Y. A., \& Umair, M. (2017). The Development of a GIS-Based Model for Campus Environmental Sustainability Assessment. Sustainability, 9, 439. https://doi.org/10.3390/su9030439

Azar, C., Holmberg, J., \& Lindgren, K. (1996). Socio-ecological indicators for sustainability. Ecological Economics, 18, 89-112. https://doi.org/10.1016/0921-8009(96)00028-6

Balsa-Barreiro, J., Yingcheng, L., Morales, A., \& Pentland, A. (2019). Globalization and the shifting centers of gravity of world's human dynamics: Implications for sustainability. Journal of Cleaner Production, 239, 117923. https://doi.org/10.1016/j.jclepro.2019.117923

Batalhão, A. C. S., Teixeira, D., Godoi, E. L., \& Prates, A. P. (2018). Exploring the Local Sustainability Approach Using Indicators. Journal of Management and Sustainability, 8(4), 39-53. https://doi.org/10.5539/jms.v8n4p39

Bell, S., \& Morse, S. (2018a). Introduction: Indicators and Post Truth. In S. Bell \& S. Morse (Eds.), Routledge Handbook of Sustainability Indicators (pp. 1-17). New York, NY, USA: Routledge. https://doi.org/10.4324/9781315561103-1

Bell, S., \& Morse, S. (2018b). Whats Next? In S. Bell \& S. Morse (Eds.), Routledge Handbook of Sustainability Indicators (pp. 453-555). New York, NY, USA: Routledge. https://doi.org/10.4324/9781315561103-34

Bixler, R. P., Lieberknecht, K., Leite, F., Felkner, J., Oden, M., Richter, S. M., ... \& Thomas, R. (2019). An Observatory Framework for Metropolitan Change: Understanding Urban Social-Ecological-Technical Systems in Texas and Beyond. Sustainability, 11, 3611. https://doi.org/10.3390/su11133611

Bockstaller, C., \& Girardin, P. (2003). How to validate environmental indicators. Agricultural Systems, 76, 639653. https://doi.org/10.1016/S0308-521X(02)00053-7

Bork, C. A., de Souza, J. F., de Oliveira Gomes, J., Canhete, V. V., \& De Barba, D. J. (2016). Methodological tools for assessing the sustainability index (SI) of industrial production processes. The International Journal of Advanced Manufacturing Technology, 87(5-8), 1313-1325. https://doi.org/10.1007/s00170-014-6684-8

Bossel, H. (1999). Indicators for Sustainable Development: Theory, Method, Applications. A Report to the Balaton Group. Winnipeg: International Institute for Sustainable Development.

Bryman, A. (2012). Social Research Methods. Oxford: Oxford University Press.

Büyüközkan, G., \& Karabulut, Y. (2018). Sustainability performance evaluation: Literature review and future $\begin{array}{lllll}\text { directions. Journal of Environmental } & \text { Management, 263-267. }\end{array}$ https://doi.org/10.1016/j.jenvman.2018.03.064

Cassar, L. F., Conrad, E., Bell, S., \& Morse, S. (2013). Assessing the use and influence of sustainability 
indicators at the European periphery. Ecological Indicators, 35, 52-61. https://doi.org/10.1016/j.ecolind.2012.07.011

Conway, G. (2007). Monitoring the state of the Solent. Marine Policy, 31(5), 632-637. https://doi.org/10.1016/j.marpol.2007.03.009

Coutinho, V., Domingues, A. R., Caeiro, S., Painho, M., Antunes, P., Santos, R., ... \& Ramos, T. B. (2017). Employee-Driven Sustainability Performance Assessment in Public Organisations. Corporate Social Responsibility and Environmental Management, 25(1), 29-46, https://doi.org/10.1002/csr.1438

Dahl, A. L. (2012). Achievements and gaps in indicators of sustainability. Ecological Indicators, 17, 14-19. https://doi.org/10.1016/j.ecolind.2011.04.032

Dalal-Clayton, B., \& Krikhaar, F. (2007). A New Sustainable Development Strategy: An Opportunity Not to Be Missed. Den Haag: RMNO Series Advice.

Davidson, K. M. (2011). Reporting Systems for Sustainability: What Are They Measuring? Social Indicators Research, 100(2), 351-365. https://doi.org/10.1007/s11205-010-9634-3

De Kerk, G. V., \& Manuel, A. R. (2008). A comprehensive index for a sustainability society: the SSI-the Sustainable Society Index. Ecological Economics, 66(2-3), 228-242. https://doi.org/10.1016/j.ecolecon.2008.01.029

De Sherebinin, R. A., Levy, M., \& Johnson, L. (2013). Indicators in Practice: How Environmental Indicators are Being Used in Policy and Management Contexts. Yale and Columbia Universities, New Haven and New York.

Domingues, A. R., Lozano, R., Ceulemans, K., \& Ramos, T. B. (2017). Sustainability reporting in public sector organisations: Exploring the relation between the reporting process and organisational change management for sustainability. Journal of Environmental Management, 192, 292-301. https://doi.org/10.1016/j.jenvman.2017.01.074

Domingues, A. R., Lozano, R., \& Ramos, T. B. (2018). Stakeholder-driven initiatives using sustainability indicators. In S. Bell \& S. Morse (Eds.), Routledge Handbook of Sustainability Indicators (pp. 379-391). London, UK: Routledge. https://doi.org/10.4324/9781315561103-25

Donnelly, A., Jones, M., O'mahony, T., \& Byrne, G. (2007). Selecting environmental indicator for use in strategic environmental assessment. Environ. Impact Asses., 27, 161-175. https://doi.org/10.1016/j.eiar.2006.10.006

Duran-Encalada, J. A., \& Paucar-Caceres, A. (2009). System Dynamics Urban Sustainability Model for Puerto Aura in Puebla, Mexico. System Practice and Action Research, 22(2), 77-99. https://doi.org/10.1007/s11213-008-9114-8

Farinha, F., Oliveira, M. J., Silva, E. M. J., Lança, R., Pinheiro, M. D., \& Miguel, C. (2019). Selection Process of Sustainable Indicators for the Algarve Region-OBSERVE Project. Sustainability, 11, 444. https://doi.org/10.3390/su11020444

Fernández, J. M., \& Selma, M. A. E. (2009). Sostenibilidad ambiental de la Región de Murcia. Murcia: Universidad de Murcia/Servicio de Publicaciones.

Fraser, E. D. G., Dougill, A. J., Mabee, W. E., Reed, M., \& MCalpine, P. (2006). Bottom up and top down: Analysis of participatory processes for sustainability indicator identification as a pathway to community empowerment and sustainable environmental management. Journal of Environmental Management, 78(2), 114-127. https://doi.org/10.1016/j.jenvman.2005.04.009

Fredericks, S. E. (2012). Justice in sustainability indicators and indexes. International Journal of Sustainable Development and World Ecology, 19(6), 490-499. https://doi.org/10.1080/13504509.2012.714807

Fulford, R. S., Krauss, I., Yee, S., \& Russel, M. (2017). A Keyword Approach to Finding Common Ground in Community-Based Definitions of Human Well-Being. Human Ecology, 45, 809-821. https://doi.org/10.1007/s10745-017-9940-3

Gallopin, G. (2018). The socio-ecological system (SES) approach to sustainable development Indicators. In S. Bell \& S. Morse (Eds.), Routledge Handbook of Sustainability Indicators (pp. 329-346). London, UK: Routledge. https://doi.org/10.4324/9781315561103-22

Gasparatos, A., El-Haram, M., \& Malcolm, H. (2008). Critical review of reductionist approaches for assessing 
the progress towards sustainability. Environmental Impact Assessment Review, 28(4-5), 286-311. https://doi.org/10.1016/j.eiar.2007.09.002

Gillen, M., \& Scanlan, J. (2004). Sustainability indicators for measuring planning outcomes e their use, development and limitations. Australian Planner, 41(2), 61-67. https://doi.org/10.1080/07293682.2004.9982355

Graute, U. (2016). Local Authorities Acting Globally for Sustainable Development. Regional Studies, 50, 19311942. https://doi.org/10.1080/00343404.2016.1161740

Graymore, M. L., Sipe, N. G., \& Rickson, R. E. (2008). Regional sustainability: how useful are current tools of sustainability assessment at the regional scale? Ecological Economics, 67(3), 362-372. https://doi.org/10.1016/j.ecolecon.2008.06.002

Graymore, M. L., Sipe, N. G., \& Rickson, R. E. (2010). Sustaining Human Carrying Capacity: A tool for regional sustainability assessment. Ecological Economics, 69(3), 459-468. https://doi.org/10.1016/j.ecolecon.2009.08.016

Guimarães, L. T., Turetta, A. P. D., \& Coutinho, H. L. C. (2010). An approach to assess the sustainability for sugarcane expansion in Mato Grosso do Sul - Brazil. Sociedade \& Natureza, 22(2), 313-327. https://doi.org/10.1590/S1982-45132010000200007

Guimarães, R. P., \& Feichas, S. A. Q. (2009). Challenges in the construction of sustainability indicators. Ambiente \& Sociedade, 12(2), 307-323. https://doi.org/10.1590/S1414-753X2009000200007

Gutowska, J., Sleszynski, J., \& Grodzinska-Jurczak, M. (2012). Selecting Sustainability Indicators for Local Community - Case Study of Milanowek Municipality, Poland. Problemy Ekorozwoju 7 (2), 77-86. https://ssrn.com/abstract $=2133977$

Guy, G. B., \& Kibert, C. J. (1998). Developing indicators of sustainability: US experience. Building Research and Information, 26, 39-45. https://doi.org/10.1080/096132198370092

Hai, L. T., Hai, P. H., Ha, P. T. T., Ha, N. M., Dai, L. T., Hoa, P. V., ... \& Cam, L. V. (2014). A System of Sustainability Indicators for the Province of Thai Binh, Vietnam. Social Indicators Research, 116(3), 661679. https://doi.org/10.1007/s11205-013-0315-x

Hák, T., Janousková, S., \& Moldan, B. (2016). Sustainable Development Goals: A need for relevant indicators. Ecological Indicators, 60, 565-573. https://doi.org/10.1016/j.ecolind.2015.08.003

Hák, T., Janoušková, S., Moldan, B., \& Dahl, A. L. (2018). Closing the sustainability gap: 30 years after "Our Common Future", society lacks meaningful stories and relevant indicators to make the right decisions and build public support. Ecological Indicators, 87, 193-195. https://doi.org/10.1016/j.ecolind.2017.12.017

Hák, T., Kovanda, J., \& Weinzettel, J. (2012). A method to assess the relevance of sustainability indicators: Application to the indicator set of the Czech Republic's Sustainable Development Strategy. Ecological Indicators, 17, 46-57. https://doi.org/10.1016/j.ecolind.2011.04.034

Hedlund-de Witt, A. (2014). Rethinking Sustainable Development: Considering How Different Worldviews Envision "Development" and "Quality of Life". Sustainability, 6(11), 8310-8328. https://doi.org/10.3390/su6118310

Hildén, M., \& Rosenström, U. (2008). The use of indicators for sustainable development. Sustainable Delopementent, 16, 237-240. https://doi.org/10.1002/sd.375

Hoernig, H., \& Seasons, M. (2004). Monitoring of indicators in local and regional planning practice: concepts and issues. Planning Practice \& Research, 19(1), 81-99. https://doi.org/10.1080/0269745042000246595

Hoko, Z., \& Hertle, J. (2006). An evaluation of the sustainability of a rural water rehabilitation project in Zimbabwe. Physics and Chemistry of the Earth, 31(15-16), 699-709. https://doi.org/10.1016/j.pce.2006.08.038

Holden, M. (2013). Sustainability indicator systems within urban governance: Usability analysis of sustainability indicators systems as boundary objects. Ecological Indicators, 32, 89-96. https://doi.org/10.1016/j.ecolind.2013.03.007

Huovila, A., Bosch, P., \& Airasinen, M. (2019). Comparative analysis of standardized indicators for Smart sustainable cities: What indicators and standards to use and when? Cities, 89, 141-153. https://doi.org/10.1016/j.cities.2019.01.029 
Janoušková, S., Hák, T., Nečas, V., \& Moldan, B. (2019). Sustainable Development—A Poorly Communicated Concept by Mass Media. Another Challenge for SDGs? Sustainability, 11, 3181. https://doi.org/10.3390/su11113181

Jeníček, V. (2013). Modification of sustainability indicators. Agricultural Economics, 59, 160-166. https://doi.org/10.17221/12/2012-AGRICECON

Kelly, E., Latruffe, L., Desjeus, Y., Ryan, M., Uthes, S., Diazabakana, A., ... \& Finn, J. (2018). Sustainability indicators for improved assessment of the effects of agricultural policy across the EU: Is FADN the answer? Ecological Indicators, 89, 903-911. https://doi.org/10.1016/j.ecolind.2017.12.053

Kelly, R., \& Moles, R. (2002). The Development of local Agenda 21 in the mid-west region of Ireland: a case study in interactive research and indicator development. J. Environ. Plan. Manage., 45, 889-912,

Latawiec, A. E. \& Agol, D. (2016). Conclusions-Sustainability Indicators in Practice: Lessons Learned from the Past, Directions for the Future. Sustainability Indicators in Practice, 16-18. https://doi.org/10.1515/9783110450507-018

Lozano, R., \& Huisingh, D. (2011). Inter-linking issues and dimensions in sustainability reporting. Journal of Cleaner Production, 19, 99-107. https://doi.org/10.1016/j.jclepro.2010.01.004

Malovics, G., Toth, M., \& Gebert, J. (2009). A critical analysis of sustainability indicators and their applicability on the regional level (pp. 1186-1192). Cers 2009-3rd Central European Conference in Regional Science, International Conference Proceedings - Young Scientists Articles, ed. M. Bucek.

Martins, M. F., \& Cândido, G. A. (2015). Urban Sustainability Indicators Systems: The Challenges of the Process of Measurement, Analysis and Monitoring. Sustentabilidade em Debate, 6(2), 138-154. https://doi.org/10.18472/SustDeb.v6n1.2015.12686

Mascarenhas, A., Coelho, P., Subtil, E., \& Ramos, T.B. (2010). The role of common local indicators in regional $\begin{array}{lllll}\text { sustainability assessment. } & \text { Ecological }\end{array}$ https://doi.org/10.1016/j.ecolind.2009.11.003

Mascarenhas, A., Nunes, L. M., \& Ramos, T. B. (2014). Exploring the self-assessment of sustainability indicators by different stakeholders. Ecological Indicators, 39, 75-83. https://doi.org/10.1016/j.ecolind.2013.12.001

Mascarenhas, A., Nunes, L. M., \& Ramos, T. B. (2015). Selection of sustainability for planning: combining stakeholders' participation and data reduction techniques. Journal of Cleaner Production, 92, 295-307. https://doi.org/10.1016/j.jclepro.2015.01.005

Mayer, A. L. (2008). Strengths and weakness of common sustainability indices for multidimensional systems. Environment International, 34, 277-291. https://doi.org/10.1016/j.envint.2007.09.004

Meadows, D. (1998). Indicators and. Information Systems for Sustainable Development: A Report to the Balaton Group. Hartland Four Corners: The Sustainability Institute.

Michael, F. L., Noor, Z. Z., \& Figueroa, M. J. (2014). Review of urban sustainability indicators assessment-Case study between Asian countries. Habitat International, 44, 491-500. https://doi.org/10.1016/j.habitatint.2014.09.006

Milman, A., \& Short, A. (2008). Incorporating resilience into sustainability indicators: An example for the urban water sector. Global Environmental Change-Human and Policy Dimensions, 18, 758-767. https://doi.org/10.1016/j.gloenvcha.2008.08.002

Moldan, B., Janouskova, S., \& Hák, T. (2012). How to understand and measure environmental sustainability: Indicators and targets. Ecological Indicators, 17, 4-13. https://doi.org/10.1016/j.ecolind.2011.04.033

Moreno, P. S., Fidélis, T., Ramos, T. B. (2014). Measuring and comparing local sustainable development through common indicators: Constraints and achievements in practice. Cities, 39, 1-9. https://doi.org/10.1016/j.cities.2014.02.003

Moreno-Pires, S., \& Fidelis, T. (2012). A proposal to explore the role of sustainability indicators in local governance contexts: The case of Palmela, Portugal. Ecological Indicators, 23, 608-615. https://doi.org/10.1016/j.ecolind.2012.05.003

Morse, S. (2016). Measuring the Success of Sustainable Development Indices in Terms of Reporting by the Global Press. Social Indicators Research, 125, 359-375. https://doi.org/10.1007/s11205-014-0847-8 
Munier, N. (2011). Methodology to select a set of urban sustainability indicators to measure the state of the city, and performance assessment. Ecological Indicators, 11(5), 1020-2016. https://doi.org/10.1016/j.ecolind.2011.01.006

Nogueiro, L., \& Ramos, T. B. (2014). The integration of environmental practices and tools in the Portuguese local public administration. Journal of Cleaner Production, 76, 20-31. https://doi.org/10.1016/j.jclepro.2014.03.096

Nourry, M. (2008). Measuring sustainable development: Some empirical evidence for France from eight alternative indicators. Ecological Indicators, 67(3), 441-456. https://doi.org/10.1016/j.ecolecon.2007.12.019

Parris, T. M., \& Kates, R. W. (2003). Characterizing and measuring sustainable development. Annual Review of Environment and Resources, 28, 559-586. https://doi.org/10.1146/annurev.energy.28.050302.105551

Perrini, F., \& Tencati, A. (2006). Sustainability and stakeholder management: the need for new corporate performance evaluation and reporting systems. Business Strategy and the Environment, 308, 296-308. https://doi.org/10.1002/bse.538

Pintér, L., Hardi, P., \& Bartelmus, P. (2005). Indicators of Sustainable Development: Proposals for a Way Forward - Discussion Paper Prepared under a Consulting Agreement on behalf of the UN Division for Sustainable Development. New York: International Institute for Sustainable Development. Retrieved from https://www.iisd.org/pdf/2005/measure_indicators_sd_way_forward.pdf

Pintér, L., Hardi, P., Martinuzzi, A., \& Hall, J. (2018). Bellagio Stamp. In S. Bell \& S. Morse (Eds.), Routledge Handbook of Sustainability Indicators (pp. 21-41) London: Routledge. https://doi.org/10.4324/9781315561103-2

Pintér, L., Hardi, P., Martinuzzi, A., \& Hall., J. (2012). Bellagio STAMP: Principles for sustainability assessment and measurement. Ecological Indicators, 17, 20-28. https://doi.org/10.1016/j.ecolind.2011.07.001

Pissourios, I. A. (2013). An interdisciplinary study on indicators: A comparative review of quality-of-life, macroeconomic, environmental, welfare and sustainability indicators. Ecological Indicators, 34, 420-427. https://doi.org/10.1016/j.ecolind.2013.06.008

Pope, J., Bond, A., Hugé, J., \& Morrinson-Saunders, A. (2017). A Reconceptualising sustainability assessment. Environ. Impact Assess. Rev., 62, 205-215. https://doi.rog/10.1016/j.eiar.2016.11.002

Ramos, T. B. (2009). Developing of regional sustainability indicators and the role of academia in this process: the Portuguese practice. Journal of Cleaner Production, 17, 1101-1115. https://doi.org/10.1016/j.jclepro.2009.02.024

Ramos, T. B. (2019). Sustainability Assessment: Exploring the Frontiers and Paradigms of Indicator Approaches. Sustainability, 11, 824. https://doi.org/10.3390/su11030824

Ramos, T. B., \& Caeiro, S. (2010). Meta-performance evaluation of sustainability indicators. Ecological Indicators, 10(2), 157-166. https://doi.org/10.1016/j.ecolind.2009.04.008

Ramos, T. B., Caeiro, S., \& de Melo, J. J. (2004). Environmental indicator frameworks to design and assess environmental monitoring programs. Impact Assessment and Project Appraisal, 22, 47-62. https://doi.org/10.3152/147154604781766111

Reinhardt, J., Liersch, S., Abdeladhim, M. A., Diallo, M., Dickens, C., Fournet, S., ... \& Walz, A. (2018). Systematic evaluation of scenario assessments supporting sustainable integrated natural resources management: evidence from four case studies in Africa. Ecology and Society, 23(1), 5. https://doi.org/10.5751/ES-09728-230105

Ridolfi, R., Andreis, D., Panzieri, M., \& Ceccherini, F. (2008). The application of environmental certification to the Province of Siena. Journal of Environmental Management, 86, 390-395. https://doi.org/10.1016/j.jenvman.2006.04.013

Rinne, J., Lyytimäki, J., \& Kautto, P. (2013). From sustainability to well-being: Lessons learned from the use of sustainable development indicators at national and EU level. Ecological Indicators, 35, 35-42. https://doi.org/10.1016/j.ecolind.2012.09.023

Rogers, S. H., Gardner, K. H., \& Carlson, C. H. (2013). Social Capital and Walkability as Social Aspects of Sustainability. Sustainability, 5, 3473-3483. https://doi.org/10.3390/su5083473 
Rogmans, T., \& Ghunaim, M. (2016). A framework of evaluating sustainability indicators in the real estate industry. Ecological Indicators, 66, 603-611. https://doi.org/10.1016/j.ecolind.2016.01.058

Ronseström, U. (2018). Sustainable Development Indicators, Finland: Going from Large Descriptive Sets to Target- Oriented Actively Used Indicators. In S. Bell \& S. Morse (Eds.), Routledge Handbook of Sustainability Indicators (pp. 321-328). London, UK: Routledge. https://doi.org/10.4324/9781315561103-21

Santana-Medina, N., Franco-Maass, S., Sanchez-Vera, E., Imbernon, J., \& Nava-Bernal, G. (2013). Participatory generation of sustainability indicators in a natural protected area of Mexico. Ecological Indicators, 25, 1-9. https://doi.org/10.1016/j.ecolind.2012.09.002

Santos, R., Antunes, P., Baptista, G., Mateus, P., \& Madruga, L. (2006). Stakeholder participation in the design of environmental policy mixes. Ecological Economics, 60(1), 100-110. https://doi.org/10.1016/j.ecolecon.2005.11.025

Saunders, M. N. K., Thornhill, A., \& Lewis, P. (2012). Research Methods for Business Students (6th ed.). Harlow, Essex, England: Pearson Education Limited.

Schliep, R., Walz, U., Sukopp, U., \& Heiland, S. (2018). Indicators on the Impacts of Climate Change on Biodiversity in Germany_Data Driven or Meeting Political Needs? Sustainability, 10, 3959. https://doi.org/10.3390/su10113959

Shen, L., Ochoa, J. J., Shah, M. N., \& Zhang, X. (2011). The application of urban sustainability indicators - A comparison between various practices. Habitat International, 35(1), 17-29. https://doi.org/10.1016/j.habitatint.2010.03.006

Souto, R. D., Pollete, M., \& Kampel, M. (2009). Evaluation of Sustainability Indicators for the Coastal Zone of Rio de Janeiro, Brazil. Journal of Coastal Research, 56, 1311-1315. https://www.jstor.org/stable/25738001

Tanguay, G. A, Rajaonson, J., Lefebvre, J. F., \& Lanoie, P. (2010). Measuring the sustainability of cities: An analysis of the use of local indicators. Ecological Indicators, 10, 407-418. https://doi.org/10.1016/j.ecolind.2009.07.013

Tasaki, T., \& Kameyama, Y. (2015). Sustainability Indicators: Are We Measuring What We Ought to Measure? Global Environmental Research, 19, 147-154.

UN - United Nations. (1992). Agenda 21. Rio de Janeiro: United Nations Conference on Environment \& Development. Brazil, 3 to 14 June 1992. Retrieved from https://sustainabledevelopment.un.org/content/documents/Agenda21.pdf

Uysal, M., \& Sirgy, M. J. (2019). Quality-of-life indicators as performance measures. Annals of Tourism Research, 76, 291-300. https://doi.org/10.1016/j.annals.2018.12.016

Valentin, A., \& Spangenberg, J. H. (2000). A guide to community sustainability indicators. Environmental Impact Assessment Review, 20, 381-392. https://doi.org/10.1016/S0195-9255(00)00049-4

Van Dijk, A., Mount, R., Gibbons, P., Vardon, M., \& Canadell, P. (2014). Environmental reporting and accounting in Australia: Progress, prospects and research priorities. Science of the Total Environment, 473, 338-349. https://doi.org/10.1016/j.scitotenv.2013.12.053

Verma, P., \& Raghubanshi, A. S. (2018). Urban sustainability indicators: Challenges and opportunities. Ecological Indicators, 93, 282-291. https://doi.org/10.1016/j.ecolind.2018.05.007

Waas, T., Hugé, J., Block, T., Wright, T., Benitez-Capistros, F., \& Verbruggen, A. (2014). Sustainability Assessment and Indicators: Tools in a Decision-Making Strategy for Sustainable Development. Sustainability, 6(9), 5512-5534. https://doi.org/10.3390/su6095512

Zang, Y., \& Guindon, B. (2006). Using satellite remote sensing to survey transport-related urban sustainability Part 1: Methodologies for indicator quantification. International Journal of Applied Earth Observation and Geoinformation, 8(3), 149-164. https://doi.org/10.1016/j.jag.2005.08.005

Zinkernagel, R., Evans, J., \& Neij, L. (2018). Applying the SDGs to Cities: Business as Usual or a New Dawn? Sustainability, 10, 3201. https://doi.org/10.3390/su10093201 


\section{Copyrights}

Copyright for this article is retained by the author, with first publication rights granted to the journal.

This is an open-access article distributed under the terms and conditions of the Creative Commons Attribution license (http://creativecommons.org/licenses/by/4.0/). 